\title{
Towards Circular Economy through Waste to Biomass Energy in Madagascar
}

\author{
Ling Qin, ${ }^{1,2,3}$ Mengjun Wang, ${ }^{1}$ Jinfu Zhu, ${ }^{4}$ Yuhu Wei, ${ }^{5}$ Xintao Zhou, ${ }^{5}$ and Zheng He $\mathbb{D}^{1}$ \\ ${ }^{1}$ School of Civil Engineering, Central South University, Changsha 410075, China \\ ${ }^{2}$ College of Civil Engineering and Architectural, Guangxi University, Nanning 530004, China \\ ${ }^{3}$ Guangxi Key Laboratory of Disaster Prevention and Structural Safety, Guangxi University, Nanning 530004, China \\ ${ }^{4}$ Department of Civil Engineering, Xi'an Jiaotong-Liverpool University, Suzhou, Jiangsu 215123, China \\ ${ }^{5}$ School of Civil Engineering, Anhui Jianzhu University, Hefei, Anhui 230601, China \\ Correspondence should be addressed to Zheng He; zhenghethan@gmail.com
}

Received 8 May 2021; Accepted 28 May 2021; Published 8 June 2021

Academic Editor: Shaohui Wang

Copyright ( 2021 Ling Qin et al. This is an open access article distributed under the Creative Commons Attribution License, which permits unrestricted use, distribution, and reproduction in any medium, provided the original work is properly cited.

\begin{abstract}
Biomass energy, contributing to about $80 \%$ of the total energy supply, is considered an important energy source in Madagascar. Although around $80 \%$ of energy use comes from biomass energy, the current application method of biomass in Madagascar is still in the earliest stage, which is not safe and sustainable. This is because the main form of biomass energy used in Madagascar is still solid charcoal and wood, and the technology is limited. Thus, it is necessary to search for better ways to utilize biomass energy in Madagascar because of high prices of traditional energy carriers and massive environmental pollution. This paper reviews the following: (1) a variety of available biomass wastes for energy in Madagascar including farming residuals, animal wastes, and forest wastes, as well as urban and industrial organic wastes; (2) advanced technologies, such as gasification, torrefaction, and fermentation, that can convert these wastes to biomass energy in forms with higher energy efficiency such as biogas, biocoal briquette, and ethanol fuel, which can not only help to achieve resource utilization of wastes and circular economy but also ease the energy crisis faced by Madagascar; and (3) Madagascar focused on the development of biomass energy with strategic policies and programs. International assistance also contributes to future promotion of biomass energy. It identifies several areas where research is urgently required to adopt instrumental policies to ensure that both rural development objectives and renewable energy targets are met with financial support from the government and international assistance.
\end{abstract}

\section{Introduction}

Energy security and declining of fossil fuel resources have led to several environmental problems and have attracted widespread concerns from many economies around the globe, both developing and developed $[1,2]$. Demand for renewable energy as well as associated services, to meet the requirement of essential human needs and further socioeconomic development, is increasing over time [3-5].

Biomass energy can be produced from various biomass stocks including forest, agricultural products, livestock, crops, and organic wastes [5-7]. It is a renewable source of clean energy containing a complicated mix of carbon, nitrogen, hydrogen, and oxygen. Many countries have identified the socioeconomic value and environmental value of biomass energy, and they have promoted the use of biomass energy through instrumental policies as well as financial support [8-11].

Madagascar, an island country located at the southern tip of the Indian Ocean, is one of the least developed countries globally [12]. Figure 1 shows the percentage share of various energy resources in Madagascar up to September 2018 [13]. Electricity is still scarce in Madagascar, in which only about $20 \%$ of the population has access to this form of modern energy $[13,14]$. In rural areas, only about $5 \%$ of the population has access to electricity [15]. Although there is a rich reserve of oil in Madagascar, its fields are untapped [16]. The major source that fulfills the energy need in Madagascar 
is biomass energy, accounting for $80 \%$ of the total energy consumption [13].

Biomass energy consumption is in practice in Madagascar since ancient times. Figure 2 shows the composition of biomass energy used in Madagascar [13]. Firewood is the most important source of biomass energy in Madagascar accounting for $85 \%$ of the total amount. Charcoal makes up $12.5 \%$ of biomass energy consumption. Biomass energy from other sources only contributes $2.5 \%$. These data indicate that the application of biomass energy in Madagascar in still in the earliest stage [17]. Most biomass energy is used directly for cooking from the forest. It is actually unsafe and not environment-friendly to utilize the biomass energy in the solid form directly as it will generate a considerable amount of pollutants like ash and smoke $[18,19]$. Meanwhile, residents have to keep cutting down the forest to meet their energy needs, resulting in severe loss of biodiversity and land desertification [20,21]. Therefore, conversion of waste to biomass has been encouraged by the Madagascar government to address the associated problems $[22,23]$. Many subsidies are offered to support the development of waste to biomass. Application of advanced biomass technology also promotes the future utilization of biomass energy [24-26].

This paper identifies a variety of available waste resources, which can be converted to biomass energy in Madagascar. The objective of this study was to conduct a systematic review of applying advanced technologies for conversion of waste to biomass energy and also biomass electricity generation in Madagascar. Government policies to support the promotion of biomass energy are mentioned as well. Biomass energy seems to be one of the best renewable energy sources to achieve a circular economy for Madagascar.

\section{Available Biomass Wastes in Madagascar}

Biomass energy refers to the energy stored in biological organic matter in the form of chemical energy transferred from solar energy through photosynthesis of plants [27]. All energy sources from plants and animals in organic matter, except fossil fuels, are biomass energy [28]. They usually include wood, forest wastes, farming residues, aquatic plants, animal wastes, energy crops, and urban and industrial organic wastes [29-31]. Conversion of waste to biomass energy is the way for sustainable development and realizing the virtuous circle of ecology. These various available waste sources for biomass energy production have different production characteristics and different energy efficiencies, from the perspectives of processing methods, energy utilization methods, clean production levels, etc.

2.1. Farming Residues. Farming is the most important industry contributing about $30 \%$ of the total GDP in Madagascar. About $51.35 \%$ of the cultivated land produces primarily rice, followed by cassava and then corn $[32,33]$. Industrial products, such as cotton, spice, coffee, and flax, have been developed for a long time in Madagascar. Massive agricultural residues, such as grain dust, wheat straw, and hazelnut shell, storing a considerable amount of biomass energy, are therefore produced [34]. Based on survey and data collection, output of each crop and available residues each year [35] are compiled in Table 1.

These farming residues can provide a considerable amount of raw materials for biomass energy production and ease the energy shortage in Madagascar.

2.2. Animal Wastes. Animal husbandry is also an important economic sector of Madagascar, whose beef and buffalo output in 2019 totaled 161,902 tonnes, poultry output 85,388 tonnes, and eggs' primary output 25,393 tonnes [36]. The livestock inventories of cattle of Madagascar ranks first in Africa, known as the "country of cattle" $[36,37]$. These animals generate a huge amount of wastes like dung every day. At present, the disposal method of animal waste in Madagascar is mainly to directly dump or use as biological fertilizer, which not only fails to make effective use of biomass but also easily causes excessive microorganisms and eutrophication in water bodies [38]. In fact, animal wastes can be regarded as a significant source of biomass energy in Madagascar [39]. If the animal waste is converted into renewable clean energy, it can not only make full and effective use of resources to relieve the energy shortage but also reduce the environmental pollution caused by the waste.

2.3. Forest Wastes. Almost all of Madagascar is located in the tropical region in which climate is affected by the wind system and altitude. The southeast coast has a typical tropical rainforest climate with an average annual temperature of $24^{\circ} \mathrm{C}$ and an annual precipitation of $2000-3000 \mathrm{~mm}$. It is hot and humid all year round and seasonal change is not obvious. Dense tropical vegetation and forests grow here. Statistics show that over 20\% of the land in Madagascar in covered with forests [40-43]. A large amount of forest wastes are generated, including scattered timber, residual branches, leaves and wood chips in forest tending and thinning operations; branches, sawdust, tops, sheeting, and cutting heads in wood harvesting and processing; and forestry byproducts of waste such as shells and nuts [44-46]. As for these forest wastes, Madagascar generally adopts the traditional treatment methods of landfill and incineration. Only a few parts can be resource-utilized [47]. In fact, forest waste contains a large amount of lignin, cellulose, hemicellulose, and some other organic substances $[48,49]$, which can be converted to biomass energy. It is not only environmentally friendly but also economical.

2.4. Urban and Industrial Organic Wastes. Madagascar's industrial base is very weak. Apart from a small amount of mining, Madagascar's industry is dominated by light industry. Agricultural products' processing industry accounts for a large proportion of Madagascar's industries, whose products mainly include edible oil, canned food, flour, sugar, tapioca powder, meat, and fish. In recent years, the enterprises in the labor-intensive export duty-free areas mainly 
focusing on needles and textiles have developed rapidly [50-52]. Most enterprises are located in the industrial area in the south of Antananarivo [52, 53]. Specific industrial structure and relatively concentrated enterprise distribution make it significant and convenient to recycle and resourceutilize the urban and industrial organic wastes to produce biomass energy. However, the resource rate of Madagascar's urban and industrial wastes is still very low. Future development of urban and industrial waste management is required in Madagascar with regard to both technologies and government policy systems.

\section{Biomass Energy Conversion Technologies}

It is clear that Madagascar has very rich raw materials for waste conversion to biomass energy through some modern technologies. This section briefly introduces several biomass energy conversion technologies, including gasification, torrefaction, and fermentation, that can be used in Madagascar.

\subsection{Gasification. Gasification refers to the transformation} process in which the pyrolysis of biomass wastes produces combustible gas combined with $\mathrm{CO}, \mathrm{H}_{2}$, or $\mathrm{CH}_{4}$, through thermal chemical reaction under the condition of high temperature and hypoxia [54]. Gasifier is the main equipment of biomass gasification reaction. It is found that compared with solid biomass fuels such as firewood and charcoal, biogas is much more efficient [55].

Biomass stream processing (BSP) is the most common technology for biomass gasification. It is a steam-assisted thermochemical conversion process aimed at increasing the energy density of biomass raw materials, and is a promising method for converting biomass waste into high-energy biogas. It allows biomass wastes to be heated from $250^{\circ} \mathrm{C}$ to $400^{\circ} \mathrm{C}$ in an atmospheric steam environment and efficiently converted into biogas in about 1 hour $[55,56]$. Figure 3 gives a schematic representation of the scale of the BSP technology [55-59]. Firstly, water is pumped by a diaphragm pump from a storage vessel into the evaporator. And then, the water flows through an electrically heated steel tube and the steam generated is heated further to reaction temperature before it is being injected as superheated steam into the reactor. Secondly, biomass is fed continuously to the electric oven. Thirdly, steam feed temperature is constantly monitored by a K-type thermocouple at the steam inlet of auger reactor. Finally, the purge stream is directed to a condenser for offline aqueous phase analysis. Biogas is therefore generated.

Uncomplicated technology and high socioeconomic and environmental benefits make it possible to develop and prompt BSP technology in developing countries. Currently, BSP technology is successfully being practiced in many developing countries such as Philippines and India, which efficiently addresses the problem of energy shortage for local residents. These examples prove that implementation of BSP technology in Madagascar is feasible.
3.2. Torrefaction. When biomass is directly consumed, the utilization and efficiency are very low, as it has a lower energy density than fossil fuels such as coal or diesel. Many studies have shown that the torrefaction can increase the energy density of biomass to equal to or even greater than the energy level of coal. Figure 4 shows the general reaction process of torrefaction [60-62]. The inert gas $\mathrm{N}_{2}$ is injected into the flowmeter, and then it is injected into a reactor to react with the biomass. After the reaction, volatile gas is obtained and injected into the pipe device shown in the figure. Finally, the permanent gas is discharged and compressible liquid is collected.

When heat is sufficiently applied to the biomass under controlled thermodynamic conditions, torrefying occurs, causing chemical, physical, and mechanical changes in the biomass. The torrefied biomass can be cofired with coal to reduce the import of fossil fuels and the emissions of $\mathrm{CO}_{2}$, $\mathrm{NO}_{\mathrm{x}}$, and $\mathrm{SO}_{\mathrm{x}}[63,64]$. This technology has been implemented in many African countries.

3.3. Fermentation. At present, the existing biomass fermentation modes on the market are mainly ethanol fermentation, hydrogen fermentation, and biogas fermentation $[65,66]$. Compared with ethanol fermentation and hydrogen fermentation, biogas fermentation has the advantages of high conversion rate, low technology requirement, low investment and operation cost, etc. [67]. In fact, biogas fermentation has been applied in Madagascar although it has not been promoted, which indicates that biogas fermentation is very suitable for Madagascar, especially for the rural areas because of limited technology conditions but rich raw materials [68-70]. Figure 5 shows three main steps in biogas fermentation [68-70]. First of all, biomass wastes can be hydrolyzed into monosaccharides, amino acids, glycerol, and fatty acids. And then, organic acids produced in the first stage are oxidized and decomposed into acetic acid and molecular hydrogen by bacteria-producing hydrogen and acetic acid. Finally, Methanogenic bacteria convert lowmolecular-weight compounds such as acetic acid, formic acid, hydrogen and carbon dioxide produced in previous stages into methane.

Ethanol fermentation is another common fermentation method in the conversion of waste to biomass energy. Figure 6 shows several steps of the production of ethanol fuel [71, 72]. Firstly, the biomass wastes are comminuted. Secondly, the raw materials such as cellulose or starch are converted into polysaccharides. Thirdly, ethanol is produced by the tricarboxylic acid cycle (TCA). And then, by distillation, the method of condensing obtains a kind of highpurity ethanol, and this whole product is converted into fuel ethanol by dewatering. Finally, the ethanol fuel and gasoline are mixed in a certain ratio to obtain fuel ethanol. This ethanol has good intermixing properties, and its physical and chemical properties are similar to gasoline, so it can be used as a novel type of clean automotive fuel-ethanol gasoline for vehicles. Through checking gasoline with a certain amount of ethanol, the content of $\mathrm{CO}$ and hydrocarbons was 


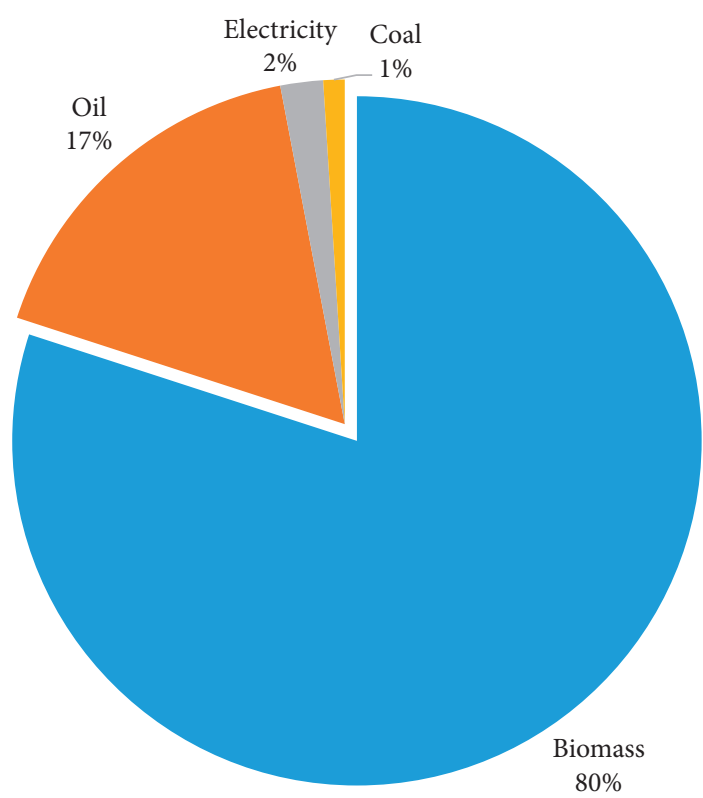

FIgURe 1: Percentage share of various energy resources in Madagascar up to September 2018.

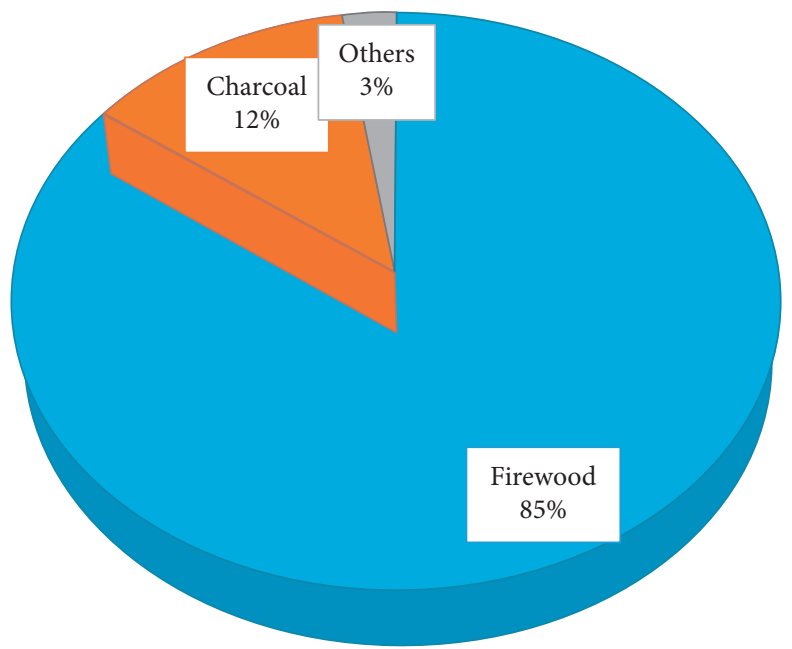

Figure 2: Percentage share of various biomass energy resources in Madagascar.

reduced by $20 \%-50 \%$ and $15 \%-40 \%$, respectively, and almost no SO2 emissions were detected.

In Madagascar, cassava, sugarcane, corn, and other crops are produced in large quantities, and the residues of these crops are rich in sugar liquid, lignocellulose, and starch. Therefore, these residues can provide rich raw materials for ethanol fuel production.

\section{Madagascar Energy Policies and International Assistance}

Energy shortage is a major obstacle to business and economic and social development in Madagascar, which was caused by the previous Madagascar government that only focused on short-term requirements and simplified problems in the design of policies. Therefore, currently, the new government attaches great importance to energy security.
Madagascar has implemented a series of policies to develop the renewable energy like biomass energy in the future. International assistance also contributes to this process significantly.

4.1. Madagascar Energy Policy. Development of energy and emission reduction programs according to distortions between energy prices and marginal costs results in the obstacles. These are the main obstacles that Madagascar faced, and it is necessary to apply an effective energy policy to overcome this gap. It is expected to obtain the maximum return on the implementation of energy policy. The Madagascar government has placed priority on renewable energy industry in national development to attract domestic and foreign capital investment in biomass energy and other renewable energy industries. 
TABLE 1: Available farming residues for biomass energy generation in Madagascar.

\begin{tabular}{lccc}
\hline Crop & Residues & Output (t/yr) & Proportion (\%) \\
\hline Paddy & Stalks, husk & $4,737,965$ & 45.58 \\
Cassava & Stalks & $3,008,895$ & 28.95 \\
Maize & Stalks, cobs & 441,914 & 3.96 \\
Ipomoea batatas & Stalks & 919,127 & 8.84 \\
Potato & Stalks & 225,850 & 2.17 \\
Kidney bean & Stalks, husk & 82,130 & 0.79 \\
Butter bean & Stalks, husk & 15,210 & 0.15 \\
Peanut & Stalks, husk & 59,495 & 0.57 \\
Coffee & Husk, pruning and wastes & 39,760 & 0.38 \\
Pepper & Stalks & 3,275 & 0.03 \\
Clove & Fronds, pruning wastes & 9,535 & 0.09 \\
Vanilla & Stalks & 3,910 & 0.04 \\
Cocoa & Husk, fronds & 7,633 & 0.07 \\
Tobacco & Stalks & 2,499 & 0.02 \\
Tea & Pruning and wastes & 311 & 0.00 \\
Litchi & Husk & 184,396 & 1.77 \\
Sugarcane & Stalks, husk & 683,166 & 6.57 \\
\hline
\end{tabular}

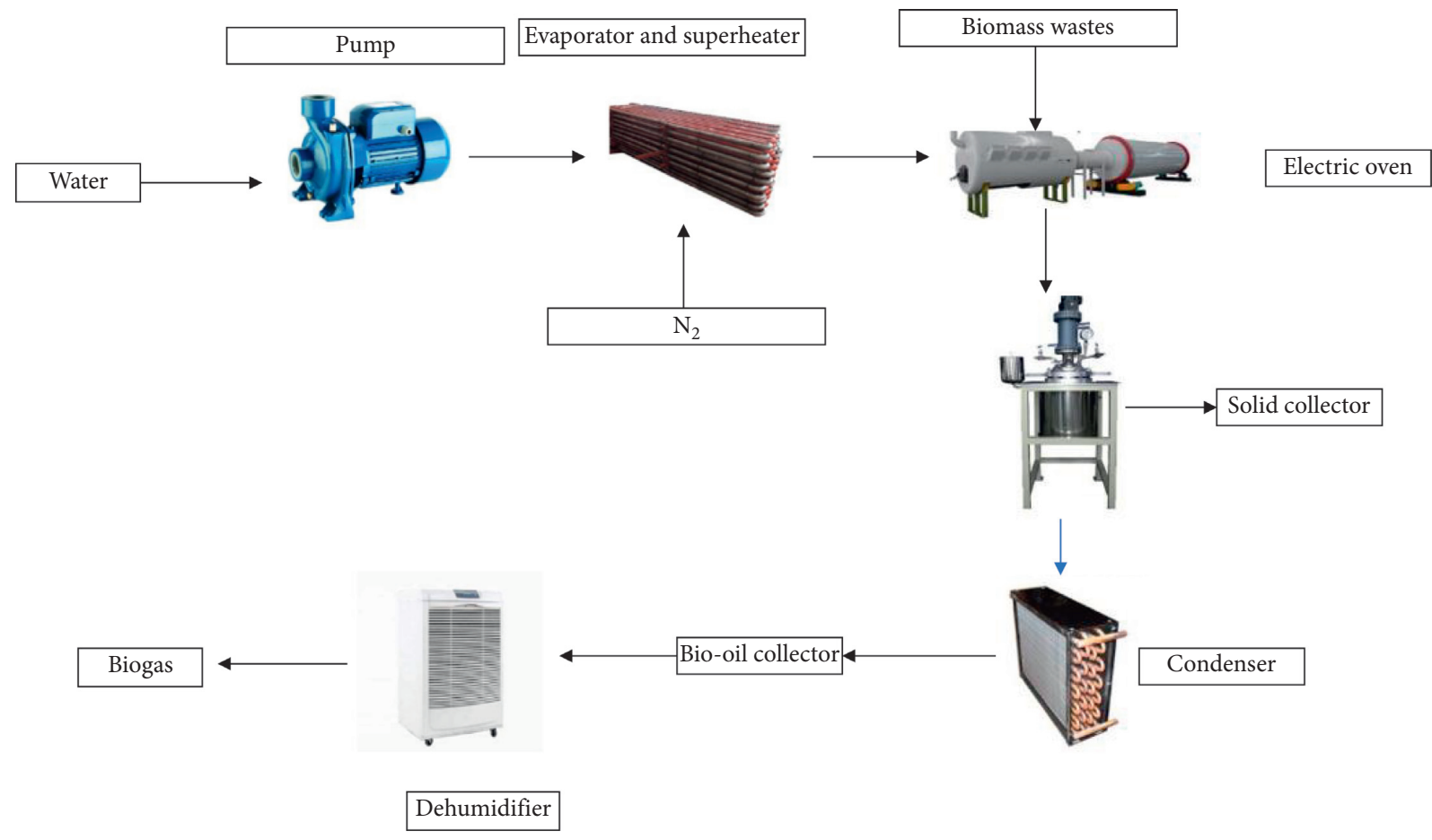

FIGURE 3: Schematic process of the BSP process.

The Government of Madagascar has announced that the imported facilities for renewable energy can get a valueadded tax or can be exempted from the tariffs. Economic Development Board of Madagascar (EDBM) released a guideline "Renewable Energy Sector and Electricity SubSector Actors 2019" [73]. This guideline is divided into English and French versions, covering 12 categories including government departments, development partners, financial institutions, nongovernmental organizations, law firms, and agents. It collected practical information of related institutions, including address, telephone number, website, and so on, which can provide convenience to international investors. In addition, Madagascar tries to prompt advanced renewable technologies. For example, two cities (Ambanja and Ambilobe) were selected as renewable energy demonstration plots in 2017 and technology support and fiscal support were provided by the Madagascar Government to develop biogas power generation [74]. Since 2018, biogas has become the main energy source for local residents.

Madagascar's fiscal 2019 budget report indicates that the Madagascar government will continue to enhance the development of renewable energy including biomass energy and achieve $50 \%$ of electricity penetration by 2024 [73]. 


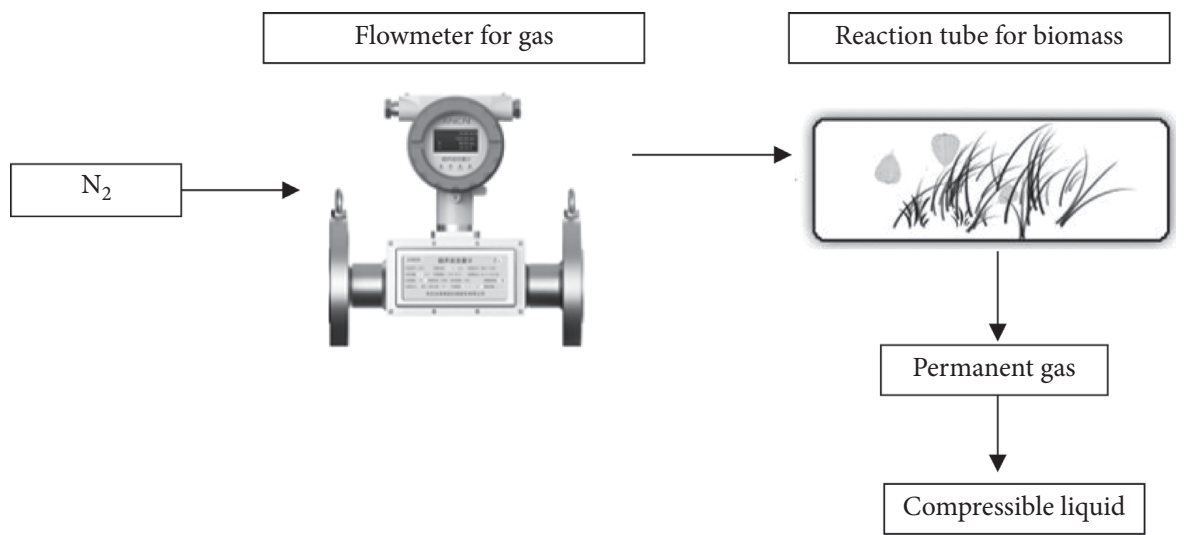

FIgURE 4: Schematic process of the torrefaction process.

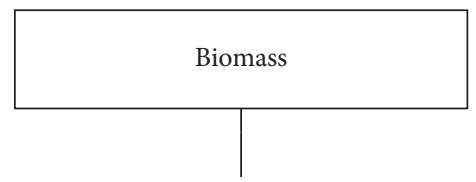

Hydrolysis

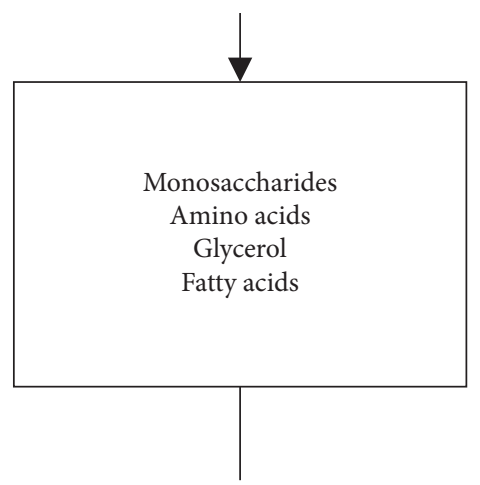

Acid production

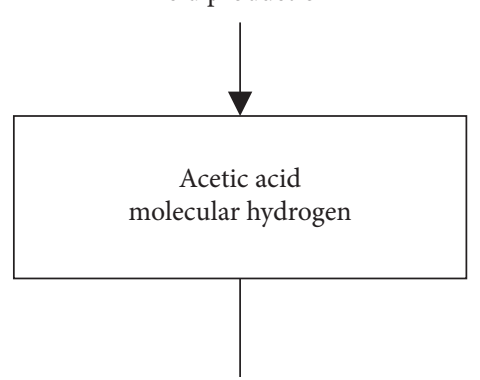

Gas production

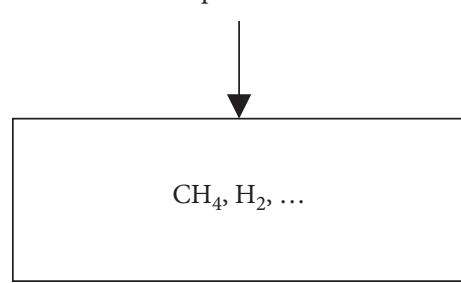

Figure 5: Schematic process of the biogas fermentation process. 


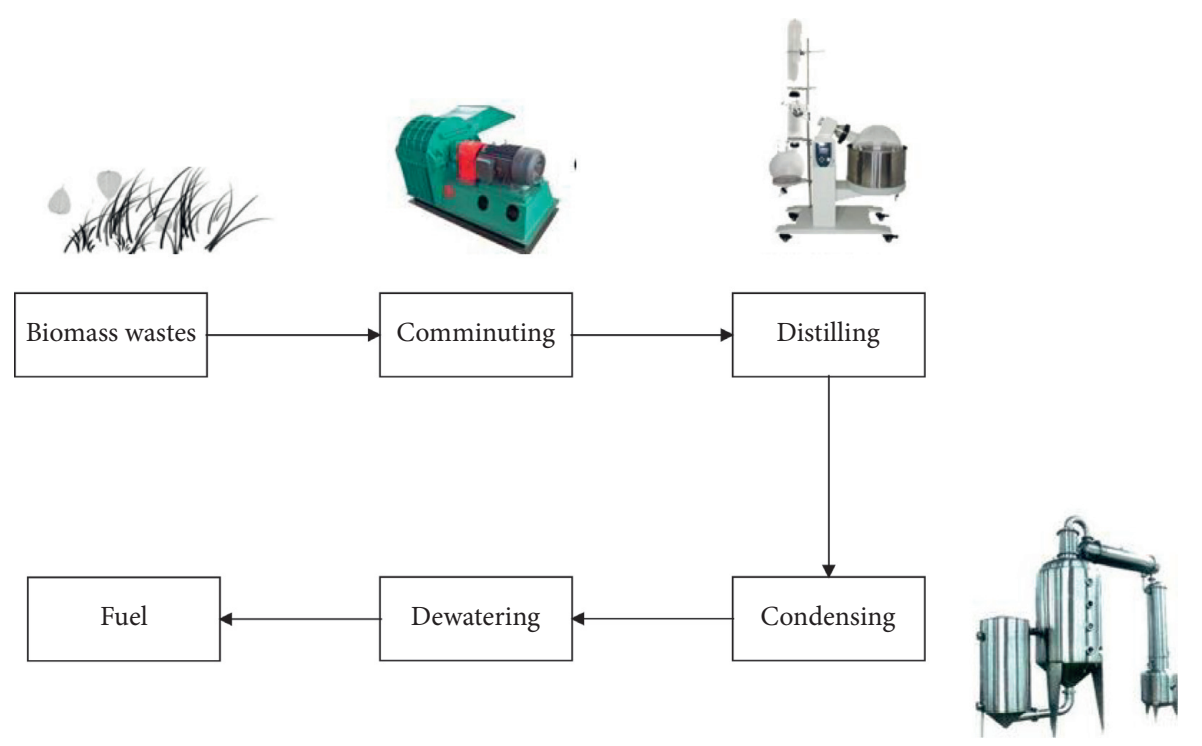

FIgURE 6: Schematic process of the ethanol fermentation process.

4.2. International Assistance from China and Germany. Madagascar is one of the least developed countries in Africa. Limited economic and technology conditions severely obstruct the future development of waste to biomass energy here. Therefore, international assistance helps a lot in this process. This section presents support from China and Germany.

4.2.1. Assistance from China. The diplomatic relations between China and Madagascar maintain steady development in recent decades. Since China and Madagascar formally established ambassadorial diplomatic relations in 1972, China-Madagascar pragmatic cooperation has achieved fruitful results [75]. The Ministry of Commerce of China proposed "the Belt and Road Initiative (B\&R)" in 2013, advocating the concept of sustainable development, and it promotes Chinese enterprises to provide support to the renewable energy industry in Madagascar [75]. For example, Chengdu DeTong Environmental Engineering Co., Ltd. has built a 30-square-meter box-type human manure and municipal organic waste biogas project in Tananarive along with the Bill \& Melinda Gates Foundation in 2015. The disposal capacity of municipal organic waste reached $780 \mathrm{~kg}$ and biogas production rate reached $0.35 \mathrm{~m}^{3} / \mathrm{kg} \mathrm{VS} / \mathrm{d}$ [76]. According to the Economic and Commercial Counsellor's Office of the Embassy of China in Madagascar, China's stock of investment reached $\$ 766$ million and the direct investment reached \$71.20 million in 2017 in Madagascar, including a large portion in renewable energy industry [77].

4.2.2. Assistance from Germany. Madagascar's government has signed a memorandum of understanding with an Africafocused financing agency (RLSF) to improve the renewable energy installed capacity through eliminating the insurance and financing pitfalls of the past. RLSF is a fund set up by Array Technology Industry (ATI) and German KfW Bank (KfW), which reduces project financing costs while protecting developers from delays in payments, through a state-owned utility (JIRAMA) [78]. The support fund initially received $\$ 63.2$ million from the German federal ministry for economic cooperation and development. Madagascar is the sixth signatory after Benin, Burundi, Malawi, Uganda and Zambia. Previously, lots of projects may fail without guarantees. The cooperation with RLSF has a positive impact on the development of the energy industry in Madagascar; for example, the renewable energy projects obtained funds and reached the financial closure stage through the guarantees from RLSF. In addition, the amount of guarantee by RLSF and Absa Bank is equal to the income of independent generator from power station in 3-6 months. According to Vonjy Andriamanga (Minister of Water, Energy and Oil of Madagascar), RLSF is an important tool to support the development of renewable energy projects that contribute to achieve the strategic objectives set out in the energy performance contract.

\section{Conclusions}

At present, $80 \%$ of the total energy supply is from biomass energy, which is considered an important energy source in Madagascar. However, the current application method of biomass in Madagascar is still in the earliest stage, which is not safe and sustainable. Also, it is not adopted for the requirement of sustainable urban development and environmental protection [79]. Although there is a long history of using biomass energy in Madagascar, the method of application is still in the earliest stage.

Hence, this paper identified the resource and the potential of the conversion of waste to biomass energy. Biomass wastes in a wide variety and different forms are available in Madagascar such as farming residuals, animal wastes, and forest wastes, as well as urban and industrial wastes [80]. Converting these biomass wastes to energy has obvious socioeconomic benefits and environmental benefits. This paper also introduces some advanced conversion 
technologies for the conversion of waste to biomass, which can be used in Madagascar. Gasification converted biomass wastes to combustible gas; torrefaction can increase the energy density in solid biomass energy and be used to produce biocoal briquette; fermentation can transfer these biomass wastes to biogas or ethanol fuel. Advanced conversion technologies can not only improve the efficiency of energy utilization but also reduce the cost of power generation [81]. Development and promotion of waste to biomass energy require the participation of the government. The Government of Madagascar has set a series of policies, including tax preference and fiscal subsidies, to encourage the application of renewable energy like biomass energy. With the limited economic and technology conditions, support from other nations such as Germany and China also plays an important role in the conversion of waste to biomass energy process in Madagascar.

In conclusion, conversion of waste to biomass seems to be the feasible approach to address the energy problem and achieve circular economy in Madagascar although it still has a long way to go.

\section{Data Availability}

All the datasets generated for this study are included within the article.

\section{Conflicts of Interest}

All the authors declare no conflicts of interest.

\section{Acknowledgments}

The authors wish to acknowledge the financial support provided by the Scientific Research Foundation of Guangxi University (Grant no. XJZ140395).

\section{References}

[1] A. Cherp, J. Jewell, V. Vinichenko, N. Bauer, and E. De Cian, "Global energy security under different climate policies, gdp growth rates and fossil resource availabilities," Climatic Change, vol. 136, no. 1, pp. 83-94, 2016.

[2] W. Qiang and Z. Kan, "A framework for evaluating global national energy security," Applied Energy, vol. 188, pp. 19-31, 2017.

[3] T.-C. Chiu, Y.-Y. Shih, A.-C. Pang, and C.-W. Pai, "Optimized day-ahead pricing with renewable energy demand-side management for smart grids," IEEE Internet of Things Journal, vol. 4, no. 2, pp. 374-383, 2017.

[4] F. C. Robert, G. S. Sisodia, and S. Gopalan, "A critical review on the utilization of storage and demand response for the implementation of renewable energy microgrids," Sustainable Cities and Society, vol. 40, pp. 735-745, 2018.

[5] M. A. Zehir, A. Batman, and M. Bagriyanik, "Review and comparison of demand response options for more effective use of renewable energy at consumer level," Renewable and Sustainable Energy Reviews, vol. 56, pp. 631-642, 2016.

[6] C. Field, J. Campbell, and D. Lobell, "Biomass energy: the scale of the potential resource," Trends in Ecology \& Evolution, vol. 23, no. 2, pp. 65-72, 2008.
[7] M. G. Guimarães, N. A. Viana, F. R. Malafaia et al., "Evaluation of brasilia wastewater sludge as a biomass resource for the production of energy by gasification simulation," International Journal of Sustainable Engineering, vol. 11, no. 1, pp. 1-8, 2017.

[8] G. Lourinho and P. Brito, "Assessment of biomass energy potential in a region of Portugal (alto alentejo)," Energy, vol. 81, pp. 189-201, 2015.

[9] F. Bilgili and I. Ozturk, "Biomass energy and economic growth nexus in $\mathrm{g} 7$ countries: evidence from dynamic panel data," Renewable and Sustainable Energy Reviews, vol. 49, pp. 132-138, 2015.

[10] W. D. Zhang, L. Zhang, C. H. Zhang, and Y. U. Dan, "Assessment of the potential of forest biomass energy in China," Journal of Beijing Forestry University, vol. 336, no. 3, pp. 873-878, 2015.

[11] H. P. Komala and A. G. D. Prasad, "Utilization pattern of biomass energy and socioeconomic dimensions associated with yelandur, Karnataka, India," International Journal of Energy \& Environmental Engineering, vol. 5, no. 2-3, pp. 1-7, 2014.

[12] J. Caspermeyer, "No one is an island: the history of human genetic ancestry in Madagascar," Molecular Biology and Evolution, vol. 33, no. 9, pp. 2478-2479, 2016.

[13] "Energy profile in madagascar," 2018, http://www. nengyuanjie.net/article/18630.html.

[14] G. Vecchi and N. A. Andriamihaja, An Evaluation of the Welfare Impact of Higher Energy Prices In Madagascar, World Bank, Washington, DC, USA, 2007.

[15] K. R. Daka and J. Ballet, "Children's education and home electrification: a case study in northwestern Madagascar," Energy Policy, vol. 39, no. 5, pp. 2866-2874, 2011.

[16] C. Nwapi and O. Nliam, "Eia legislation and sustainable development of oil sands projects in Madagascar: a critical assessment," Journal of Energy \& Natural Resources Law, vol. 36, pp. 1-27, 2017.

[17] S. Andrea, R. Josef, L. I. Benjamin et al., "Jatropha mahafalensis oil from Madagascar: properties and suitability as liquid biofuel," Energy for Sustainable Development, vol. 17, no. 4, pp. 326-330, 2013.

[18] R. A. Obande, S. Omeji, and M. Ityumbe, "Organoleptic assessment and nutritive values of clarias gariepinus smoked using coal and firewood," Pakistan Journal of Nutrition, vol. 11, no. 9, pp. 762-764, 2012.

[19] E. Ruuska, "Unsustainable charcoal production as a contributing factor to woodland fragmentation in southeast Kenya," Fennia-International Journal of Geography, vol. 191, no. 1, pp. 58-75, 2013.

[20] T. F. Allnutt, S. Ferrier, G. Manion et al., "A method for quantifying biodiversity loss and its application to a 50 -year record of deforestation across Madagascar," Conservation Letters, vol. 1, no. 4, pp. 173-181, 2010.

[21] A. Chaudhary, S. Pfister, and S. Hellweg, "Spatially explicit analysis of biodiversity loss due to global agriculture, pasture and forest land use from a producer and consumer perspective," Environmental Science \& Technology, vol. 50, no. 7, pp. 3928-3936, 2016.

[22] K. Naudin, E. Scopel, A. L. H. Andriamandroso et al., "Tradeoffs between biomass use and soil cover. the case of rice-based cropping systems in the lake alaotra region of Madagascar," Experimental Agriculture, vol. 48, no. 2, pp. 194-209, 2012.

[23] B. D. Neimark and T. M. Healy, "Small-scale commodity frontiers: the bioeconomy value chain of castor oil in 
Madagascar," Journal of Agrarian Change, vol. 18, no. 2, pp. 1-27, 2018.

[24] J. Kopyscinski, T. J. Schildhauer, and S. M. A. Biollaz, "Production of synthetic natural gas (SNG) from coal and dry biomass - a technology review from 1950 to 2009," Fuel, vol. 89, no. 8, pp. 1763-1783, 2010.

[25] A. Bosmans, I. Vanderreydt, D. Geysen, and L. Helsen, "The crucial role of waste-to-energy technologies in enhanced landfill mining: a technology review," Journal of Cleaner Production, vol. 55, no. 14, pp. 10-23, 2013.

[26] C. Vaneeckhaute, V. Lebuf, E. Michels et al., "Nutrient recovery from digestate: systematic technology review and product classification," Waste and Biomass Valorization, vol. 8 , no. 1, pp. 21-40, 2017.

[27] N. K. Boardman, "Energy from the biological conversion of solar energy," Philosophical Transactions of the Royal Society of London. Series A, Mathematical and Physical Sciences, vol. 295 , no. 1414 , pp. 477-489, 1980.

[28] C. Ciubota-Rosie, M. Gavrilescu, M. Macoveanu, and V. I. Popa, "Biomass-an important renewable source of energy in Romania," Environmental Engineering and Management Journal, vol. 7, no. 5, pp. 559-568, 2008.

[29] S. Maiti, S. Dey, S. Purakayastha, and B. Ghosh, "Physical and thermochemical characterization of rice husk char as a potential biomass energy source," Bioresource Technology, vol. 97, no. 16, pp. 2065-2070, 2006.

[30] F. Karaosmanoglu, E. Tetik, B. Gurboy, and I. Sanli, "Characterization of the straw stalk of the rapeseed plant as a biomass energy source," Energy Sources, vol. 21, no. 9, pp. 801-810, 1999.

[31] L. Cao, L. Z. Yi, and J. Sun, "The application status and prospect of biomass energy source in the fuel production and power generation," Pratacultural Science, vol. 26, no. 9, pp. 49-53, 2009.

[32] M. R. Vololona, M. Kyotalimye, T. Thomas, and M. Waithaka, "East african agriculture and climate change: a comprehensive analysis - madagascar," The Economic Consequences of Climate Change, vol. 29, no. 2, pp. 109-128, 2015.

[33] J. C. Randrianarisoa and B. Minten, Agricultural Production, Agricultural Land and Rural Poverty in Madagascar, Social Science Electronic Publishing, Rochester, NY, USA, 2003.

[34] A. Kumar, N. Kumar, P. Baredar, and A. Shukla, "A review on biomass energy resources, potential, conversion and policy in India," Renewable and Sustainable Energy Reviews, vol. 45, pp. 530-539, 2015.

[35] Ministry of Commerce, Report on the Development of Agriculture in Madagascar, Ministry of Commerce, Beijing, China, 2014, http://www.mofcom.gov.cn/article/i/jyjl/k/201403/ 20140300521498.shtml.

[36] Madagascar-Production of Beef and Buffalo Meat, Knoema, New York, NY, USA, 2019, https://knoema.com/atlas/ Madagascar/topics/Agriculture/Live-Stock-ProductionProduction-Quantity/Production-of-beef-and-buffalo-meat.

[37] G. Nicolas, B. Durand, R. Duboz, R. Rakotondravao, and V. Chevalier, "Description and analysis of the cattle trade network in the Madagascar highlands: potential role in the diffusion of Rift Valley fever virus," Acta Tropica, vol. 126, no. 1, pp. 19-27, 2013.

[38] P. Rahagalala, H. Viljanen, J. Hottola, and I. Hanski, "Assemblages of dung beetles using cattle dung in Madagascar," African Entomology, vol. 17, no. 1, pp. 71-89, 2009.

[39] J. Olowoyeye, "Comparative studies on biogas production using six different animal dungs," Journal of Energy Technologies \& Policy, vol. 3, 2013.
[40] M. Page, "Madagascar," 2021, http://www.ahay.org/wiki/ Main_Page.

[41] G. Vieilledent, O. Gardi, C. Grinand et al., "Bioclimatic envelope models predict a decrease in tropical forest carbon stocks with climate change in Madagascar," Journal of Ecology, vol. 104, no. 3, pp. 703-715, 2016.

[42] V. S. Malika, W. Katherinej, and G. Lindsey, "Evidence for drought and forest declines during the recent megafaunal extinctions in Madagascar," Journal of Biogeography, vol. 37, no. 3, pp. 506-519, 2010.

[43] M. Virahsawmy, "Ecosystem management in Madagascar during global change," Conservation Letters, vol. 2, no. 4, pp. 163-170, 2010.

[44] J. A. R. Añón, F. F. López, J. P. Castiñeiras, J. P. Ledo, and L. N. Regueira, "Calorific values and flammability for forest wastes during the seasons of the year," Bioresource Technology, vol. 52, no. 3, pp. 269-274, 1995.

[45] M. C. J. Bier, A. B. P. Medeiros, J. S. de Oliveira et al., "Liquefied gas extraction: a new method for the recovery of terpenoids from agroindustrial and forest wastes," The Journal of Supercritical Fluids, vol. 110, pp. 97-102, 2016.

[46] L. Bufalino, G. H. D. Tonoli, T. G. Costa et al., "Nanocellulose films from amazon forest wood wastes: structural and thermal properties," Key Engineering Materials, vol. 668, pp. 110-117, 2015.

[47] D. Haladová, O. Cundr, and J. Pecen, "Selection of optimal anaerobic digestion technology for family sized farm use-case study of southwest Madagascar," Agricultura Tropica Et Subtropica, vol. 44, 2011.

[48] R. Cornelia, D. Ariane, D. Marie-France et al., "Effect of base hydrolysis on the chemical composition of organic matter of an acid forest soil," Organic Geochemistry, vol. 36, no. 2, pp. 239-249, 2005.

[49] F. Spellman, Forest-based Biomass Energy: Concepts and Applications, CRC Press, Boca Raton, FL, USA, 2011.

[50] B. Sarrasin, "The mining industry and the regulatory framework in Madagascar: some developmental and environmental issues," Journal of Cleaner Production, vol. 14, no. 3, pp. 388-396, 2006.

[51] Madagascar-Industrial production, Trading Economics, New York, NY, USA, 2016, https://zh.tradingeconomics.com/ madagascar/industrial-production.

[52] "Hasina (Madagascar)," 2014, https://en.wikipedia.org/wiki/ Hasina.

[53] A. S. Collins, "Madagascar and the amalgamation of central gondwana," Gondwana Research, vol. 9, no. 1, pp. 3-16, 2006.

[54] M. D. C. Arantes, L. M. Mendes, G. F. Rabelo et al., "Gasification of lignocellulosic materials for generation of electric energy," Ciênc Florest, vol. 18, no. 3-4, pp. 525-533, 2008.

[55] C. Srinivasakannan and N. Balasubramanian, "The significance of indirectly heated gasifiers for the generation of medium calorific value syngas through biomass gasification," Energy Sources, Part A: Recovery, Utilization, and Environmental Effects, vol. 32, no. 17, pp. 1579-1586, 2010.

[56] D. Diedericks, E. van Rensburg, and J. F. Görgens, "Enhancing sugar recovery from sugarcane bagasse by kinetic analysis of a two-step dilute acid pretreatment process," Biomass and Bioenergy, vol. 57, no. 4, pp. 149-160, 2013.

[57] D. Diedericks, E. van Rensburg, and J. F. Görgens, "Fractionation of sugarcane bagasse using a combined process of dilute acid and ionic liquid treatments," Applied Biochemistry and Biotechnology, vol. 167, no. 7, pp. 1921-1937, 2012.

[58] C. T. Massie, "Biomass-to-energy feasibility study," Office of Scientific \& Technical Information Technical Reports, 2002. 
[59] S. Barskov, M. Zappi, P. Buchireddy et al., "Torrefaction of biomass: a review of production methods for biocoal from cultured and waste lignocellulosic feedstocks," Renewable Energy, vol. 142, pp. 624-642, 2019.

[60] J. Shankar Tumuluru, S. Sokhansanj, J. R. Hess, C. T. Wright, and R. D. Boardman, "REVIEW: a review on biomass torrefaction process and product properties for energy applications," Industrial Biotechnology, vol. 7, no. 5, pp. 384-401, 2011.

[61] J. M. Commandré and A. Leboeuf, "Volatile yields and solid grindability after torrefaction of various biomass types," Environmental Progress \& Sustainable Energy, vol. 34, no. 4, pp. 1180-1186, 2015.

[62] M. J. C. V. D. Stelt, H. Gerhauser, J. H. A. Kiel, and K. J. Ptasinski, "Biomass upgrading by torrefaction for the production of biofuels: a review," Biomass \& Bioenergy, vol. 35, no. 9, pp. 3748-3762, 2011.

[63] M. Witczak, M. Walkowiak, and W. Cichy, "Pre-treatment of biomass by torrefaction-preliminary studies," Drewno, vol. 185 , no. 185 , pp. 89-96, 2011.

[64] C. Zhang, S.-H. Ho, W.-H. Chen, Y. Xie, Z. Liu, and J.-S. Chang, "Torrefaction performance and energy usage of biomass wastes and their correlations with torrefaction severity index," Applied Energy, vol. 220, pp. 598-604, 2018.

[65] B.-F. Liu, G.-J. Xie, R.-Q. Wang et al., "Simultaneous hydrogen and ethanol production from cascade utilization of mono-substrate in integrated dark and photo-fermentative reactor," Biotechnology for Biofuels, vol. 8, no. 1, 2015.

[66] N. Q. Ren, M. L. Gong, and D. F. Xing, "Continuous operation of hydrogen bio-production reactor with ethanol-type fermentation," Huan Jing Ke Xue, vol. 25, no. 6, pp. 113-116, 2004.

[67] A. Bauer, H. Mayr, K. Hopfner-Sixt, and T. Amon, "Detailed monitoring of two biogas plants and mechanical solid-liquid separation of fermentation residues," Journal of Biotechnology, vol. 142, no. 1, pp. 56-63, 2009.

[68] V. Klassen, O. Blifernez-Klassen, Y. Hoekzema, J. H. Mussgnug, and O. Kruse, "A novel one-stage cultivation/ fermentation strategy for improved biogas production with microalgal biomass," Journal of Biotechnology, vol. 215, pp. 44-51, 2015.

[69] R. Wirth, G. Lakatos, T. Böjti et al., "Metagenome changes in the mesophilic biogas-producing community during fermentation of the green alga scenedesmus obliquus," Journal of Biotechnology, vol. 215, pp. 52-61, 2015.

[70] D. Montag and B. Schink, "Biogas process parameters-energetics and kinetics of secondary fermentations in methanogenic biomass degradation," Applied Microbiology and Biotechnology, vol. 100, no. 2, pp. 1019-1026, 2016.

[71] G. R. Cysewski and C. R. Wilke, "Process design and economic studies of alternative fermentation methods for the production of ethanol," Biotechnology \& Bioengineering, vol. 20, no. 9, pp. 1421-1444, 2010.

[72] L. A. D. C. Meleiro, F. J. Von Zuben, and R. M. Filho, "Constructive learning neural network applied to identification and control of a fuel-ethanol fermentation process," Engineering Applications of Artificial Intelligence, vol. 22, no. 2, pp. 201-215, 2009.

[73] Ministry of Commerce, Guide to Agencies in the Field of Renewable Energy and Electricity in Madagascar, Ministry of Commerce, Beijing, China, 2019, http://mg.mofcom.gov.cn/ article/jmxw/201906/20190602873442.shtml.

[74] Ministry of Commerce, Two Regions Of Madagascar Take The Lead In Trialling New Biogas Energy, Ministry of Commerce,
Beijing, China, 2017, http://www.mofcom.gov.cn/article/i/ jyjl/k/201711/20171102671224.shtml.

[75] "Seven meetings with foreign dignitaries in 12 days as xi jinpin's spring diplomacy gets under way," 2017, http://news. cctv.com/2017/03/29/ ARTIgTz0NFaNSfXfX1Mmb31C170329.shtml.

[76] BMGF Gates Foundation Madagascar-30 Square Boxes of Human Manure and Municipal Organic Waste Biogas Project, Chengdu DeTong Environmental Engineering Co., Ltd, Chengdu, China, 2015, http://www.chengdu-detong.com/zh/ cn-references/\#international-projects.

[77] Ministry of Commerce, China Invested a Record Amount in Madagascar in 2017, Ministry of Commerce, Beijing, China, 2018, http://mg.mofcom.gov.cn/article/jmxw/201811/ 20181102811353.shtml.

[78] A fund backed by the German government is expected to ease obstacles to the development of renewable energy in Madagascar, Solarbe, Beijing, China, 2019, https://news.solarbe. com/201905/06/306590.html.

[79] Z. He and H. Chen, "An ISM-based methodology for interrelationships of critical success factors for construction projects in ecologically fragile regions: take korla, China as an example," Applied Sciences, vol. 11, no. 10, p. 4668, 2021.

[80] J. L. Hao, B. Cheng, W. Lu et al., "Carbon emission reduction in prefabrication construction during materialization stage: a BIM-based life-cycle assessment approach," Science of The Total Environment, vol. 723, Article ID 137870, 2020.

[81] B. Cheng, Y. Wei, W. Zhang et al., "Evolutionary game simulation on government incentive strategies of prefabricated construction: a system dynamics approach," Complexity, vol. 2020, Article ID 8861146, 11 pages, 2020. 